\title{
IPTEKS PERNYATAAN STANDAR AKUNTANSI PEMERINTAHAN NO 07 PADA BADAN KEPEGAWAIAN, PENDIDIKAN DAN PELATIHAN KOTA MANADO
}

\author{
Aryani K Waworundeng ${ }^{1}$, Tesalonika Onibala ${ }^{2}$, Lady Latjandu ${ }^{3}$ \\ 1,2,3 Jurusan Akuntansi, Fakultas Ekonomi dan Bisnis, Universitas Sam Ratulangi, Jl. Kampus Bahu, Manado, \\ 95115, Indonesia \\ email : aryanitann@gmail.com
}

\begin{abstract}
Pernyataan Standar Akuntansi Pemerintahan No. 07" is a standard who control about fixed assets. The scope of this standard is applied to every unit of government who report their financial statement and sets about their accounting treatments. "Badan Kepegawaian, Pendidikan, dan Pelatihan Kota Manado" duty is to help the government organize some part of government's matter in regional civil servant's management and take responsibility in financial management as an accounting entity, must carry out their duty for budget's utilization. Based on the treatment applied, result shows that recognition, measurement, disclosure, depreciation, termination and elimination already match with "Peraturan Pemerintah Nomor 71 Tahun 2010" about "Pernyataan Standar Akuntansi Pemerintah No. 07 Akuntansi Aset Tetap", but for termination and elimination of fixed assets didn't completely match with "Standar Akuntansi Pemerintahan.
\end{abstract}

Keywords: fixed assets, PSAP No. 07

\section{PENDAHULUAN}

Pemerintah sebagai pihak yang menguasai aset daerah memiliki tanggung jawab dalam pengelolaan dan pemanfaatan aset. Aset tersebut berupa aset tetap yang digunakan pemerintah dalam menjalankan kegiatan operasionalnya. Seperti yang disebutkan dalam Pernyataan Standar Akuntansi Pemerintahan Nomor 07, aset tetap merupakan aset berwujud yang jangka waktu pemakaiannya lebih dari satu tahun dalam aktivitas pemerintah agar dapat digunakan oleh masyarakat.

Aset tetap memiliki kontribusi yang berpengaruh besar dalam menjalankan tata kelola pemerintahan. Pengelolaan aset tetap yang tidak dilakukan dengan maksimal juga tidak dapat menunjang kegiatan pemerintah yang lebih efektif serta tidak dapat mewujudkan tujuan pemerintah yang baik. Pemerintah memerlukan manajemen pengelolaan dalam memanfaatkan aset yang telah diperoleh, sehingga prinsip efisiensi, efektivitas, dan transparasi dapat terlaksana. Prinsip tersebut dapat berjalan baik dengan peraturan pemerintah yang telah ditetapkan.

Badan Kepegawaian, Pendidikan dan Pelatihan Kota Manado mengemban tanggung jawab membantu pemerintah dalam melaksanakan sebagian urusan kepemerintahan di bidang manajemen pegawai negeri sipil daerah dan bertanggung jawab dalam pengelolaan keuangan sebagai entitas akuntansi, wajib melaksanakan wewenang atas penggunaan anggaran. Dengan demikian, aset tetap yang berada di BKPP Manado perlakuan akuntansinya wajib dilaporkan sesuai dengan peraturan yang telah ditetapkan.

\section{TINJAUAN PUSTAKA}

Menurut PSAP No. 07 Aset Tetap adalah aset berwujud yang memiliki jangka waktu penggunaan lebih dari satu tahun dalam untuk digunakan dalam aktifitas pemerintahan 
maupun oleh masyarakat umum. Dalam kegiatan pemerintahan tentunya dalam menjalankan segala kegiatannya pihak pemerintahan mempunyai standar akuntansi secara pemerintah sehingga menurut SAP No.07 Aset Tetap didefinisikan sebagai aset berwujud yang memilki masa manfaat lebih dari 12 (dua belas) bulan untuk digunakan dalam kegiatan pemerintah atau dimanfaatkan untuk kepentingan umum. Dalam SAP no.07 terdapat klasifikasi yang berdasarkan sifat maupun fungsinya dan penggunaannya sesuai dengan masa manfaatnya yakni : Tanah, Peralatan, Mesin, Bangunan,Jalan, irigasi dan aset tetap lainnya. Masa Manfaat yang dimaksudkan adalah periode dari suatu aset diharapkan digunakan untuk aktivitas pemerintahan dan digunakan untuk melaksanakan pelayanan publik.

Pernyataan Standar Akuntansi Pemerintahan (PSAP) No 07 membahas mengenai Pernyataan Standar Akuntansi Pemerintahan dalam lingkup pengelolaan secara akuntansi atas aset tetap. PSAP 07 dapat ditemui dalam lampiran Peraturan Pemerintah Nomor 71 Tahun 2010, yakni telah ada lampiran I.08 dimana didalamnya terdapat pembahasan seperti apa Standar Akuntansi Pemerintahan Berbasis Akrual dan dalam lampiran II.08 membahas mengenai SAP Berbasis Kas Menuju Akrual.

\section{METODE DAN TEKNIK PENERAPAN IPTEKS}

3.1 Metode Penerapan Ipteks

Penerapan metode ipteks yang dilakukan adalah dengan mengimplementasikan Pernyataan Standar Akuntansi Pemerintahan nomor 07.

\subsection{Teknik Penerapan Ipteks}

Penerapan ipteks yang digunakan yaitu (1) Klasifikasi atas Aset Tetap, (2) Pengakuan atas Aset Tetap, (3) Pengukuran atas Aset Tetap, (4) Penilaian atas Aset Tetap, (5) Penghentian dan Penghapusan atas Aset Tetap, (6) Pengungkapan atas Aset Tetap, (7) Penyusutan atas Aset Tetap.

\section{PEMBAHASAN}

\subsection{Gambaran Objek Penerapan Ipteks}

Badan Kepegawaian, Pendidikan dan Pelatihan Kota Manado adalah suatu lembaga kepemerintahan yang membantu pemerintah dalam menyelenggarakan sebagian urusan pemerintahan di bidang manajemen pegawai negeri sipil daerah. Yang berada di lingkungan Pemerintah Kota Manado. Dengan memiliki Visi "Manado Kota Cerdas 2021" dan Misi "Program Smart City sebagai infrastruktur dan sistem pengendali yang mengawali pencapaian visi melalui pelaksanaan misi yang tersimpul kedalam enam kata kunci sebagai singkatan cerdas".

\subsection{Pembahasan}

Guna mengurangi resiko kehilangan atau penggelapan Aset Tetap maka perlu adanya peninjauan dan peningkatan dalam hal tata kelola Aset Tetap dan dalam Penerapannya perlu menggunakan PSAP No.07 mengenai Akuntansi Aset Tetap secara pemerintahan yang mennyatakan bahwa pengelolaan Aset tetap ditinjau berdasarkan :

Klasifikasi Aset Tetap, Dalam hal ini klasifikasi yang dimaksudkan ialah mengelompokan secara rinci aset tetap yang dimiliki entitas berdasarkan 6 klasifikasi yang telah di tentukan dalam PSAP No.07. dan dalam penerapannya pada BKPP Kota Manado mencakup alat kantor siap pakai yang digunakan pemerintah dalam aktivitasnya sebagai layanan publik dan perlu di klasifikasikan dan perlu juga ditinjau secara berkala sehingga dapat mengurangi resiko ada aset tetap yang hilang atau tak terdata dalam klasifikasi.

Pengakuan Aset Tetap, Secara pengakuannya, menurut SAP aset tetap pada pemerintahan perlu memenuhi kriteria yakni masa manfaatnya lebih dari satu periode, biaya perolehan aset tetap dapat diukur secara andal, tidak dimaksudkan untuk dijual dalam operasi normal entintas, dan diperoleh atau dibangun dengan maksud untuk digunakan. Dan 
penerapan pada Badan Kepegawaian, Pendidikan dan Pelatihan Kota Manado diakui pada saat diterima atau kepemilikannya berpindah. Di Badan Kepegawaian, Pendidikan dan Pelatihan Kota Manado, peralatan dapat diakui ketika bukti hak atau kepemilikannya berpindah dimana bukti didalamnya berisi berita acara tentang perpindahan hak atau kepemilikan terhadap peralatan dan aset tetap lainnya.

Pengukuran Aset Tetap, Untuk pengukurannya, menurut SAP aset tetap dimiliki dan dikuasai oleh pemerintah harus dinilai dan diukur untuk dapat dilaporkan dalam neraca. Menurut SAP, aset tetap yang diperoleh atau dibangun secara swakelola jumlah nilai didasarkan dengan biaya perolehan, untuk BKPP sendiri dalam kegiatan mengadakan barang pemerintah Kota Manado menerbitkan aturan sebagai pedoman dalam melaksanakan pengadaan barang yaitu Standar Satuan Harga.

Penilaian Aset Tetap, Menurut SAP, dalam melakukan penilaian aset tetap perlu adanya aset tetap yang diperoleh dalam bentuk siap pakai, penilaiaan ini kurang lebih dalam perlakuannya sama dengan pengukuran namun pengukuran difokuskan untuk biaya dan penilaian berfokus pada masa masa manfaat. Sehingga penilaian aset tetap pada BKPP Kota Manado dilakukan untuk menyusun neraca, namun penilaian aset tetap pada BKPP Kota Manado hanya menggunakan penilai dari pegawai pada bagian umum bidang aset tetap dan penilaian dari independen berpengalaman belum digunakan. Maka dari itu, masih ada aset tetap yang dianggap hilang yang tidak tercatat di daftar aset Badan Kepegawaian, Pendidikan dan Pelatihan Kota Manado. Ini dibuktikan dengan nama barang pada KIB namun tidak tercatat nominal dari harga barang tersebut.

Penghentian dan Penghapusan Aset Tetap, Menurut SAP hal ini lebih terfokuskan pada aset tetap yang telah rusak berat dan sudah tidak dapat digunakan lagi sehingga aset tersebut perlu dihapus dari pembukuan, prosesnya sendiri penghapusan atau pelepasan aset ini memerlukan waktu cukup lama sehingga sementara menunggu surat keputuan terbit maka aset tersebut perlu dipindahkan kekelompok aset tetap lain-lain sehingga dapat diungkapkan dalam CaLK. Dalam BKPP Penghapusan aset dilakukan ketika aset tetap dinyatakan rusak berat, usang dan hilang dengan mengacu kepada UU yang berlaku. Penghentian pada BKPP Kota Manado dilakukan dengan pelepasan atau penyingkiran aset tetap.

Pengungkapan Aset Tetap, Menurut SAP, dalam pengungkapan aset tetap disajikan dalam neraca dan juga dalam CaLK. Penerapan di BKPP Pengungkapan atas aset tetap pada laporan keuangan BKPP Kota Manado disajikan dengan menilai total dari masing-masing jenis aset.

Penyusutan Aset Tetap, Menurut SAP, penyusutan terhadap aset tetap adalah penyesuaian nilai sehubungan dengan penurunan kapasitas dan manfaat dari Aset dalam hal penyusutan ada pengecualiannya dan tidak disusutkan adalah tanah dan konstruksi bangunan atau gedung. Pada BKPP Kota Manado sudah melakukan penyusutan aset tetap. Oleh karena itu pada saat penyusunan neraca sudah dikurangi akumulasi penyusutan. Penyusutan aset tetap pada BKPP Kota Manado sudah sesuai dengan SAP.

\section{KESIMPULAN DAN SARAN}

\subsection{Kesimpulan}

Kesimpulan atas penerapan yang telah dilaksanakan adalah bahwa Badan Kepegawaian Pendidikan dan Pelatihan Kota Manado sudah menerapkan perlakuan akuntansi pengakuan, pengukuran, penyusutan, pengungkapan aset tetap telah sesuai dengan PP No. 71 tahun 2010. Akan tetapi, penghapusan dan penghentian aset tetap belum sesuai dengan SAP berlaku.

\subsection{Saran}

Dalam menjaga efektifitas dan efisiensi penggunaan dari aset tetap maka Badan Kepegawaian, Pendidikan dan Pelatihan Kota Manado perlu menerapkan PP No. 71 tahun 
2010 tentang SAP No. 07 mengenai akuntansi atas aset tetap lebih intens lagi sehingga mengurangi barang yang tidak terpakai dan masa gunanya habis tanpa pemakaian.

\section{DAFTAR PUSTAKA}

Afrilinda, Aldar. (2015). Akuntansi Aset Tetap Pada Bank Nagari Cabang Pembantu UNP. Diploma thesis, UPT. Perpustakaan Unand. Universitas Andalas: Padang.

Bahtiar Arif, Muchlis, Iskandar. (2002). Akuntansi Pemerintah. Salemba Empat: Jakarta.

DPPKAD. (2012). Modul Teknis Akuntansi dan Ilustrasi Penerapan.SE.900/758/BA KD. Tidak dipublikasikan.

Effendi, R., (2015). Analisis Perlakuan Akuntansi Atas Aset Tetap Berdasarkan SAK ETAP Pada CV. Sekonjing Ogan Ilir. Volume 5. Nomor 1. Jurnal Ilmiah STIE MDP. Universitas Tridinanti Palembang: Indonesia.

Giri, Efraim Ferdinan. (2014). Akuntansi Keuangan Menengah 1 Perspektif IFRS. UPP STIM YKPN: Yogyakarta.

Kieso, Donald E, Jerry J, Weygant, Terry D, Warfield. (2002). Akuntansi Intermediate Edisi Kesepuluh Jilid 2. Erlangga: Jakarta.

Komite Standar Akuntansi Pemerintah. (2010). Standar Akuntansi Pemerintah. Salemba Empat: Jakarta.

Masipuang Y, Ilat V, Pinatik S. (2015). Analisis Perlakuan Akuntansi Aset Tetap Pada Badan Kepegawaian dan Diklat (BKD) Kota Manado. Jurnal EMBA, 10(3). FEB UNSRAT: Manado.

Purba, Marisi P. (2013). Akuntansi Keuangan Aset Tetap dan Aset Tak Berwujud. Edisi Pertama. Graha Ilmu: Yogyakarta.

Reeve J, Warren C, Duchac J, Wahyuni E, Soepriyanto G, Jusuf A, Djakman C. (2012). Pengantar Akuntansi Adaptasi Indonesia. Buku 2. Salemba Empat: Jakarta.

Riyanto, Agus. (2015). Akuntansi Pemerintah Daerah Berbasis Akrual. Cetakan Pertama. Pustaka Pelajar: Yogyakarta. 